Global Conferences Series:

Social Sciences, Education and Humanities (GCSSSEH), Volume 2, 2019

The $2^{\text {nd }}$ International Conference on Sustainable Development \& Multi-Ethnic Society

DOI: https://doi.org/10.32698/GCS.0186

\title{
The National Philosophy from the Point of View (weltaunchauung) of the Penan Community
}

\author{
Ronald Agan Tom ${ }^{1}$, Mohd Mahzan Awang ${ }^{2}$, Abdul Razaq Ahmad ${ }^{3}$ \& Anuar Ahmad ${ }^{4}$ \\ ${ }^{1234}$ Faculty of Education, The National University of Malaysia, MALAYSIA \\ E-mail: ronaldqmu@gmail.com
}

\begin{abstract}
This concept paper aims to look at the meaning of education from the perspective of the Penan community (weltaunchauung). The Penan community is a minority community living in rural Sarawak. They were originally nomadic. As a result, Penan society is lagging behind in many aspects especially in the field of education. The government-backed resettlement did not show a favourable impact on Penan student enrolment in high school. At one time, the Penans were a separate community from other people because of their remote locations. The education they receive is informal education where they only learn the skills they need for survival. The emergence of formal education now gives the Penan community no choice but to join the National education agenda. The fallout has left them unable to compete with other economically disadvantaged communities. Therefore, this concept paper is designed to look at the philosophy of education according to the Penan society. Is there anything sceptical about education today from the Penan society? It is hoped that this concept paper will provide a clearer understanding of issues pertaining to Penan society.
\end{abstract}

Keywords: Minorities, point of view, formal education

\section{Introduction}

Education is no longer something new among the community across the world. It is getting easier to get access to formal education nowadays. The ease of access to formal education has made it accessible to everyone including those in the rural areas. Formal education is critical in ensuring global competitiveness. Nowadays, the revolution in industries are booming and people must grow in line with today's modernization of industry to enable them to find future employment (Samian, 2017). The people of the rural should no longer suffer from accidental or non-accidental dropouts. The decline in Penan society today is a result of the lack of awareness of the current industrial needs. The people of the community are of the opinion that the informal education they receive is enough to enable them to complete with the outside community especially in rural areas as much as possible to place themselves in a group that fits to serve the industry sector today. This concept paper was developed to better understand the meaning of education in the Penan community.

\section{Problem Statement}

Various measures have been taken by various parties to ensure the rural and urban education gap is closer. However, this educational gap is still a long way from this point of view. Among the communities that is still experiencing serious drop in education is the Penan 
community. They are like jewels in the rural waiting to be polished. The potential is seen in them with physical strength as well as the skills they learned through informal education. Various questions have arisen as the Penan community continues to lose their education. Are they being ignored? Is the Penan community seeing formal education as something not important? What can be done to advance this society? Various studies have been conducted to address these questions. However, recent studies have largely focused on the scope of indigenous peoples in Peninsular Malaysia. Studies on the Penans should be expanded.

\section{Education in Malaysia}

Education in Malaysia is a medium designed to provide quality human capital in line with future needs. Malaysia's educational development plan is designed to achieve that goal. The plan began in 2013 and will end in 2025 (Ministry of Education Malaysia, 2013). Education in Malaysia goes from pre-education to higher education. In Malaysia, the education sector is offered not only by the government but also by the private sector which also offers education services especially at the pre-education and higher education levels.

The Malaysian Education Development Plan (PPPM) is a long-term plan to enhance the quality of existing education in Malaysia that began in early 2013 and ends in 2025. Among the key components of PPPM are access, quality, equity, unity and efficiency. Equity in PPPM means that efforts to develop education will focus more on backward areas. Today, there is a huge gap between rural and urban education. This equity is different from the concept of equality previously used where the allocation is given irrespective of the geographical and demographic position of the area. The school is also seen as a place of unity where students between ages of 7 to 17 will receive the same curriculum. The efficiency of the education system in Malaysia will also be emphasized in this PPPM whereby school management should be more effective especially in managing school finances with the current allocation. The provision that often ranks at the top of the State budget is expected to increase students' achievement. PPPM also emphasized that student access to schools will increase. Enrolment is targeted at the $100 \%$ level where there will be no further dropouts of students in both the interior and the city. Finally, PPPM also aims to improve the quality of the country's education in international assessments such as TIMSS and PISA. This is being tried by emphasizing the HOTS element in education.

\section{Education of the Penan Society}

Various efforts have been made by the government to ensure that student enrolment increases from year to year. Nevertheless, dropouts among the Penan society are still high. Existing curriculum today has changed according to the culture of the local community. This has the potential to increase students' interest in coming to school. A low percentage of graduates proves that both the indigenous people and the poor have a low level of education, if left unattended, which could lead to a decline in motivation among these students. Curriculum should be tailored to the students' cognitive level (Norwaliza, 2015). Teachers should be willing and able to find the initiative to bring this group to education. One of the things that can be done is to convey knowledge that is relevant to their culture.

Education of the Penan community has become a major issue in the education world in Sarawak as many Penan students do no continue their education after finishing high school (Egmal, 2015). Various factors contributed to this. Among the possible causes are the lack of interest in academic subjects. The different sociocultural environment at school has also contributed to this problem. This is evident when the presence of Penan students in primary schools is very high because they are near their village. In contrast to high school, they feel as if they are outside of their community. This is further underscored by the fact that they are a minority in the school. The Penan community is a community rich in arts and crafts. These knowledge are passed down by their ancestors. The people of the peninsular receive informal education by learning weaving and so forth from their older generation. To support Penan's desire to maintain their tradition, the Penan Women Project (PWP) was created. It is also to encourage this community to continue to maintain their culture. Despite the formal education received by the Penan people, their weaving and crafts are meticulous and interesting.

\section{Issues in the Penan Community Education}

The Penans are aware of the importance of education today, However, various issues and obstacles make it difficult for people to get an education. One of it is due to their low income. Their remote locations require high transportation costs to get to school. The economic resources of the Penans are so limited that they depend only on forest produce. This volatile income has left them being unable to afford the cost of education which they considered to be high. The situation of the Penan community is further complicated by the increment in the logging activities in their settlements. This has led to the decline in forest productivity.

The next issue that hit the Penans was that the school was too far away (Jeniri Amir, 2019). The school's 
position is too far from home and that they are unable to make it to school. Most of them enrolled at the beginning of the year as dorm students. However, these Penan students will not return to school if they return to their village during the school holidays. This is due to the lack of transportation as well as the cost of paying the high fare. Some of them have to board a boat for hours before boarding another vehicle to get to school. This very remote position can sometimes cause safety issues among the students. Some families are not willing to risk and let their children miss out on the educational opportunities the school offers. This has made this educational gap even more so than in other communities.

In addition, low motivation in the Penan community has led to a decline in society. The lack of role models to encourage these Penan children to come to school is also the cause of this problem. The low level of education among parents makes it hard for them to encourage their kids to come to school (Esa, 2017). Parental involvement is a key driver of children's success. Most of these parents do not even ask about their school situation or about the children's studies.

Poor communication skills in the Penan community also led to their drop in education. These people live mostly in the interior. In this area, there is not much interaction with the outside community. They only interact among themselves. This makes them feel awkward to communicate with strangers. English proficiency is also an aspect that contributes to the problem of dropout. The pursuit of Mathematics and Science in English once formed another wall of separation between this society and the world of education. They find communicating in English is very difficult for them, and this has led to their motivation to decline and the result is most of them decided not to attend school.

\section{The Future of the Penan's Education}

The government and non-governmental organizations are seen as very serious in changing the perception of education in the Penan community. However, various gaps must be bridged first to achieve this goal. Among them is bridging the ICT gap. Among the things that have been done is the recent launch of E-Lamai which is a smart move towards bridging the digital divide especially in the rural areas. ELamai was launched in Long Lamai to expose the community to the outside world (Paran, 2010). This exposure is seen as positive. The Penan community began to explore the outside world. This has also aroused their interest to explore more about the outside world and this would have a positive impact on the country's education system.
The Penan community is also seen as more motivated to get involved in education. This process should take place slowly. However, a project carried out by Sarawak Energy Berhad at one of the schools in Belaga district was seen as an eye opener to the Penans to attend school (Ismail, 2016). The project is to open the future of the Penan community education. Penan students who attend school will benefit RM2 and be included in their education fund in high school. The use of this money is solely for education purposes only. This will definitely increase the attendance of the Penan community for coming to school because they no longer need to worry about financial issues or looking for financial resources if they pursue higher education.

The Penan community is also seen as a community that accepts development. This means that they do not reject the development the country brings to them. However, they have their own meaning of development. These Penans wanted genuine development (Ibrahim, 2010). Genuine development to them us a development that does not sacrifice the environment. This community completely rejects any development related to forest opening. For them, the development they bring should not be at the expense of nature. Government-led development is viewed now as a development that does not benefit them. This led to the existence of negative or sceptical view among the Penan people about development. This also led them to reject education as part of the development agenda.

\section{Conclusion}

In conclusion, the Penans should no longer reject educational opportunities open to them. They should be one of the components in the society working together to develop a better nation. There are various problems and issues they face in order to get an education. Such matters should be resolved as soon as possible by the authorities so that they are no longer excluded from the national education agenda. There are also Penans who have succeeded in becoming millionaires and also succeeding in universities. They should play their part by inspiring other Penan children to be successful as they are.

\section{References}

[1] Abang Ismail Abang Su'ud (2016), Insentif Menggalakkan Anak Penan Pergi Ke Sekolah, Utusan Borneo Online 29 September 2016 diperolehi daripada https://www.pressreader.com/malaysia/utusan-borneosarawak/20160929/281698319235484

[2] Egmal Hj Adin \& Mohd Zaihidee Arshad (2015), Isu Pendidikan Seni Visual Etnik Penan di Baram, Sarawak: Satu Tinjauan Awal, Jurnal Seni dan Pendidikan Seni Vol. 3 (1-7) 
[3] Jeniri Amir (2019), Masyarakat etnik Penan seiring arus pemodenan, Berita Harian Online Selasa, 8 Oktober 2019, diperoleh daripada https://www.bharian.com.my/node/76691

[4] Kementerian Pendidikan Malaysia (2013), Pelan Pembangunan Pendidikan Malaysia 2013-2025.

[5] Norizan Esa \& Salasiah Che Lah (2017), Kelestarian Dan Dinamisme Kearifan Tempatan Dalam Pendidikan, Penerbit Universiti Sains Malaysia.

[6] Norwaliza Abdul Wahab \& Ramlee Mustapha (2015), Reflections on Pedagogical and Curriculum Implementation at Orang Asli Schools in Pahang. Procedia - Social and Behavioral Sciences 172 (442448.)

[7] Rania Paran (2010), Penan,IT Makin Serasi, Utusan Sarawak Online, 26 Februari 2010 diperolehi daripada http://www.utusan.com.my/utusan/info.asp?y=2010\&dt= 0226\&pub=Utusan Malaysia\&sec=Sabah_\%26_Sarawak \&pg=wb_03.htm

[8] Samion \& Azahan Awang (2017), Pendidikan Sebagai Komponen Kualiti Hidup Masyarakat Pinggir Bandar, Asian Journal of Environment, History and Heritage, Vol. 1, Issue. 1, p. 267-280.

[9] Yusliza Yakimir Abd Talib (2018), Anyaman Wanita Penan, Berita Harian Online Khamis, 20 Disember 2018 diperoleh daripada Https://Www.Hmetro.Com.My/Hati/2018/12/401378/An yaman-Wanita-Penan

[10] Zawawi Ibrahim dan NoorShah (2010), Membangun Metodologi Penyelidikan Peribumi, Kajian Malaysia, Vol. 31, No. 1, 97-100 